\title{
A verdade como fundamento abissal em Heidegger
}

\section{The truth as abissal foundation in Heidegger}

DOI: $10.12957 /$ ek.2018.34035

Dnda. Ana Cristina Reis Cunha

anareiscunha@sapo.pt

Universidade de Lisboa - Portugal

É colossal o empreendimento de Heidegger, pensar o ser no seu ser, reeditando o radicalismo de uma atitude questionadora e pensante esquecida. Indagar o insondável é próprio do homem e disso são exemplo os pensadores matinais que este autor revisitou ao procurar as primeiras tentativas de exegese do ser. Heidegger desafia-nos a perguntar pelo que não aparece, tendo presente o

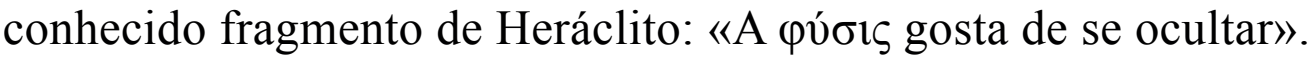

Em Heidegger, a verdade é fundamento abissal. Para melhor o entender este complexo pensamento heideggeriano é crucial analisar como interpreta o autor a temática do ser e da verdade, bem como a verdade como doação e retração e, finalmente, a verdade como sem-fundo, fundamento sem fundamento, fundamento abissal. A verdade do ser é a essência da verdade. A verdade como fundamento abissal indicia, com a sua aura de inefabilidade, de inescrutabilidade, o excesso ontológico, o mistério do ser.

PALAVRAS-ChAVE Fundamento Abissal. Ser. Verdade

Heidegger's enterprise is colossal, to think the being in his being, reediting the radicalism of a questioning and forgotten thinking attitude. Inquiring into the unfathomable is proper of man, and examples are the morning thinkers whom this author revisited as he sought the first attempts of the exegesis of being. Heidegger challenges us to ask for what does not appear, bearing in mind the well-known fragment of Heraclitus: «Фv́бıৎ likes to hide».

Heidegger considers truth as an abyssal foundation. In order to better understand this matter, it is crucial to analyze how the author interprets the theme of being and truth, as well as truth as a gift and withdrawal, and finally truth as a foundation without foundation, as an abyssal foundation. The truth of being is the essence of truth. Truth as an abyssal foundation indicates, with its aura of ineffability, of inscrutability, the ontological excess, the mystery of being. 


\begin{abstract}
A metafísica pareceu-me sempre uma forma prolongada de loucura latente. Se conhecêssemos a verdade, vê-la-iamos; tudo mais é sistema e arredores. Baste-nos, se pensarmos, a incompreensibilidade do universo; querer compreendê-lo é ser menos que homens, porque ser homem é saber que se não compreende.
\end{abstract}

Fernando Pessoa, Livro do Desassossego

\section{Introdução}

Indagar o insondável é próprio do homem e disso são exemplo os pensadores matinais que Heidegger revisitou ao procurar nas origens do pensamento metafísico ocidental as primeiras tentativas de exegese do ser.

Enquanto na era homérica sábio seria o experiente, que primava pela habilidade técnica e pela destreza, para os frequentadores do oráculo de Delfos sábio seria o que projetava luz na obscuridade. Na palavra manifestava-se ao homem a sabedoria de Deus e era através do êxtase mistérico, num total despojamento das condições do indivíduo, que se alcançava o conhecimento: a loucura era a matriz da sabedoria. Para os primevos pensadores gregos, o nosso mundo seria a aparência de um mundo oculto, do mundo onde viviam os deuses.

Heidegger recuou até aos pré-socráticos e à primeira designação filosófica

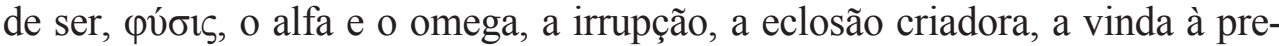
sença num fluxo que é sempre um refluxo, um retornar sobre si. O que vem à presença resulta deste movimento, que é o movimento da temporalidade. A temporalidade é a fissura, a rotura, o rasgão do uno nos múltiplos, a cisão na multiplicidade, a diferenciação ontológica radical entre o ser e os entes, ou essenciação. O ser essencia-se, temporaliza-se de uma forma específica.

A grande intuição de Heidegger foi o desenvolvimento do $\lambda$ ó $\gamma o \varsigma$ no tempo. Já para Heráclito o $\lambda o ́ \gamma o \varsigma$ era a lei do movimento do acontecimento do ser. $\mathrm{Na}$ verdade, para Heidegger, ser não é algo de substantivo, nem uma realidade abstrata, mas deve ser entendido como verbo, ação, no sentido existencial e transitivo de ser: estar a acontecer, estar aí a advir, a existir. No princípio de tudo está o ser, a ação de temporalização que traz à presença a existência. Ser é a plenitude superabundante, inesgotável, do que ainda está para chegar. O ser é inexaurível, é potencialidade, possibilidade; não pode ser presentificado num pensar representativo. Ser é acontecer, vir à presença, e tem as três dimensões temporais do passado, presente e futuro, que são formas distintas de se dar. O 
ser, no seu sentido próprio, é temporalidade. O ser é fonte de possibilidade, pelo que é, na sua dimensão de abissalidade, fundamento sem fundo.

Em Heidegger, a verdade é fundamento abissal. Para melhor entender o complexo pensamento heideggeriano acerca desta matéria será importante enveredar, num primeiro momento, pela senda do ser e da verdade.

No pensamento tardio de Heidegger a palavra fundamental é "verdade" e não "ser", uma vez que a verdade é experimentada enquanto o acontecimento do desocultamento, um irromper de carácter temporal e destinável da verdade, inesperado e único. Revisitando o pensamento grego, Heidegger pensou o ser na sua verdade, no seu estremecimento, no seu mistério e na sua plenitude de nada. A experiência do ser como evento é a dimensão abissal do nada. Ao ser, enquanto fundamento abissal, pertence o nada. No nada experimentamos a amplidão daquilo que garante a todo o ente a possibilidade de ser. O nada não é, assim, o indeterminado oposto do ente, mas pertence ao ser do ente. O nada é a outra face do ser, o lado não revelado do ser, transcendência, mistério. A melhor compreensão acerca do ser e do nada conduz-nos, por sua vez, à verdade do ser. O ser é um movimento de essenciação da verdade. A verdade do ser, como desvelamento, descobrimento, é inesgotável. Para algo 'ser' tem de se revelar, apresentar, e para que essa presença ou auto-manifestação ocorra é necessária uma clareira, um vazio. O Dasein é essa abertura necessária para que tenha lugar a presença dos entes. Dasein é a abertura na qual a presença se dá, é a clareira do ser.

A verdade é, assim, doação, mas, sendo doação, não deixa de ser, ao mesmo tempo, retração. Para uma melhor compreensão da verdade como fundamento abissal é crucial entender a verdade como doação e retração.

Heidegger desafia-nos a perguntar pelo que não aparece, tendo presente o conhecido fragmento de Heráclito: «A pv́бıৎ gosta de se ocultar». O fundamento último do mundo é algo de velado. A púбıৎ não se mostra na sua totalidade; é

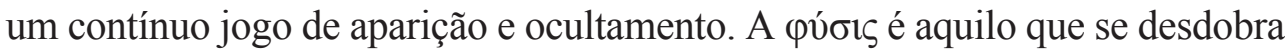
e emerge de si mesma, voltando continuamente a si mesma. Significa ser, não apenas como presença, mas também como auto-retração. $\mathrm{O}$ desocultamento não pode ter lugar sem ocultamento, como tentou fazer crer a metafísica, uma vez que o não oculto comparece como ente, que não deve ser confundido com o

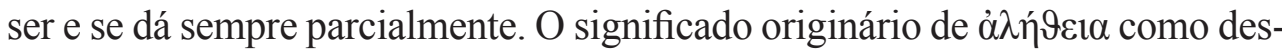
velamento, essência da verdade, perdeu-se pouco depois do alvor da metafísica, com a preeminência da proposição, do enunciado. Ao ocupar-se com o dado, o presente, a metafísica confundiu o ser com o ente, esqueceu o ocultamento e o vir à presença. Ser e existência foram erroneamente equiparados. O ser não é, 
A verdade como fundamento abissal em Heidegger
Dnda. Ana Cristina

Reis Cunha [ULisboa]

essencia-se. O ser aparece, ocultando-se. Ao investigar o ser como fundamento dos entes, a metafísica compreendeu o ser como aquilo que é constantemente presente e o ser ficou impensado na sua temporalidade. $\mathrm{O}$ ser é radicalmente temporal e intrinsecamente histórico. Heidegger designou por Ereignis o modo e o âmbito do dar-se do ser, o puro acontecimento que deixa vir os entes à presença, subtraindo-se, contudo, a esta. Ereignis é, assim, doação e retração. É retraindo-se que o ser concede aos entes vir à presença.

Todo o desvelamento pressupõe um velamento, pelo que todo o conhecimento tem como contrapartida o mistério. Foi o que designámos por excesso ontológico ou o mistério do ser no último passo na senda do estudo da verdade como fundamento abissal.

A abissalidade é o caráter retrativo da $\alpha \hat{\lambda} \eta \dot{\vartheta} \varepsilon ı$. O ser, o «é» de um ente, não está enraizado no ente, como se pudessemos extrair o ser do ente. $\mathrm{O}$ ser não mergulha as suas raízes em nenhum solo, é o sem-fundo. Dos princípios não há demonstração: o fundamento não pode estar no fundamentado. Ser é, na essência, fundamento. Mas o ser fundador não pode ter, ele próprio, um fundamento, na medida em que ele é o fundamento. Enquanto fundamento, ele é sem fundo, abissal. O ser não tem porquê. É porque é. Em Heidegger, o ser deixa de ser visto como um fundamento sólido e estável da verdade. O ser é visto como abismo e a verdade como velamento desvelante que permeia todos os entes.

\section{O Ser e a Verdade}

\subsection{O Ser e o Nada}

O ser é o mais universal dos conceitos e, por isso mesmo, sendo universal, o conceito de ser é indefinível. O ser é, também, o mais compreensível dos conceitos. Em todo o conhecer, enunciar, em todo o comportamento relativamente a um ente, em todo o comportamento relativamente a nós próprios, utilizamos o termo ser, e o termo é compreensível. Mas esta compreensão vulgar apenas mostra a incompreensibilidade do conceito.

O ser é o mais vazio e ao mesmo tempo a riqueza a partir da qual todo o ente é dotado do respetivo modo essencial do seu ser. O ser é o mais universal que se encontra em todo o ente e, portanto, o mais comum, o que perdeu toda a caracterização ou que nunca a possuiu, mas é, ao mesmo tempo, o mais único, aquele cujo 
caráter único nunca é alcançado por qualquer ente. O ser não tem igual. O que há diante do ser é o nada e talvez este seja, na sua essência tributária, do ser e apenas dele. O ser é também o mais fiável, o que nunca nos intranquiliza com uma dúvida. Todavia, o ser não nos oferece um fundamento e um solo como o ente, para o qual nos viramos, sobre o qual construímos e junto do qual nos demoramos.

A questão fundamental da metafísica é a seguinte: «Por que existe afinal ente e não antes Nada?» Mas o que é o nada? Ao interrogarmo-nos acerca do nada, estamos já a incorrer numa contradição, uma vez que o nada não pode ser definido como sendo isto ou aquilo. Quem fala do nada está já a transformá-lo em algo.

Se é certo que nunca poderemos captar o todo do ente, não menos certo é que nos encontramos no meio do ente, que, de uma ou outra maneira nos é desvelado na sua totalidade. Há uma diferença substancial entre captar o todo do ente em si e encontrar-se (em meio ao ente na sua totalidade). O primeiro é radicalmente impossível, enquanto que o segundo acontece constantemente na nossa existência. Certos estados de ânimo, como o profundo tédio, que nos leva aos abismos da existência, ou a alegria pela presença, a existência, de um ser querido, permitem que nos encontremos no meio do ente na sua totalidade.

Haverá um estado de ânimo na existência do homem que o leve à presença do próprio nada? Heidegger diz-nos que esse estado de ânimo é a angústia. A angústia manifesta o nada. O nada descobre-se na angústia, mas não como ente. A angústia não é a apreensão do nada, no entanto, o nada torna-se patente nela e através dela. Segundo o autor, a condição humana caracteriza-se pelo fato de sermos lançados na existência sem que o tenhamos escolhido. Isso espelha a nossa finitude, o nosso limite ontológico. A situação que nos precede torna-nos finitos. O Dasein é um ser em dívida, produto de um dom. Além disso, entre as várias possibilidades que lhe são oferecidas, há uma a que o homem não pode escapar, que é a morte. A morte é a possibilidade de que todas as outras possibilidades se tornem impossíveis. Ela é a possibilidade da impossibilidade de todo o projeto, da própria existência. É a possibilidade intransponível, a condição radical da nossa finitude. Heidegger considera que a existência autêntica é um ser-para-a-morte. A existência autêntica, ou seja, a existência filosófica, é a existência angustiada. O Dasein, quando se projeta no futuro, vê inscrita no futuro a possibilidade do seu não ser. A vida é negação da negação, mas limitada no tempo, por isso, o nada confunde-se com o ser.

O nada não é, assim, o indeterminado oposto do ente, mas pertence ao ser do ente. Ser e nada copertencem-se. 
O ser não se deixa representar à semelhança do ente. $\mathrm{O}$ absolutamente outro em relação ao ente é o não-ente, mas este desdobra-se como ser. No nada experimentamos a amplidão daquilo que garante a todo o ente a possibilidade de ser.

O fenómeno, considerado na fenomenologia de Husserl como o que aparece a uma consciência intencional no seu visar de objetividades, refere-se, para Heidegger, não ao ente, mas ao próprio ser como vinda à presença que possibilita o aparecer e subsistir do ente: "Só o desvelamento do ser possibilita a revelabilidade do ente" (HEIDEGGER, 1988, p. 23).

A questão do ser nunca foi adequadamente tratada, uma vez que se confundiu a presença com o presente, o ser com o ente. Desde o pensamento grego que o ser é experimentado como presença. Marlène Zarader interroga-se acerca do motivo que levou a que a presença tivesse cedido o lugar à permanência, inaugurando, assim, a sua própria retirada e o domínio do presente. É que é próprio da presença ser atravessada de ponta a ponta pela ausência e, desse modo, ocultar-se. O que caracteriza a ausência é não se dar a não ser sob a modalidade da falta em vez da plenitude. A ausência é uma maneira de não estar lá. E todavia, é nesse não estar lá que se desvela a presença autêntica, em oposição ao presente que, apesar de estar lá, nunca está a não ser como estando a ser (ZARADER, 1986, p. 223).

A presença, na sua essência, está indissociavelmente ligada à ausência e, por isso, é constituída pela sua própria ocultação. O nada não é nem negativo, nem é a meta, mas o estremecimento essencial do ser mesmo e, por isso, mais essente do que qualquer ente (HEIDEGGER, 2014 (a), p. 262).

O nada é a outra face do ser, o lado não revelado do ser, transcendência, mistério. Isto conduz-nos à questão em torno da verdade do ser.

\subsection{A Verdade do Ser}

A verdade é comumente pensada como correção, concordância do enunciado com a coisa que enuncia, ou de uma coisa com o que previamente se pensa dela. A experiência da verdade, de Platão a Husserl, é sempre a da adequação das nossas representações com a essência das próprias coisas.

Segundo Heidegger, todavia, a verdade é sempre a verdade do ser. " $A$ verdade pertence à essência do Ser" (HEIDEGGER, 1997, p. 113). Não é uma característica do pensamento humano, não é adequação do objeto ao pensamento. É um desvelamento do ser: “ 'Verdade' quer dizer a essência do verdadeiro. Pensamo-la a partir da recordação da palavra dos gregos. 'A $\lambda \hat{\eta} \vartheta \varepsilon 1 \alpha$ significa o não-estar-encoberto do ente" (HEIDEGGER, 2014 (b), pp. 49-50). A verdade do ser, como desvelamento, descobrimento, é inesgotável. 
A verdade como fundamento abissal em Heidegger

Com o progressivo desenvolvimento da metafísica perdeu-se a noção de

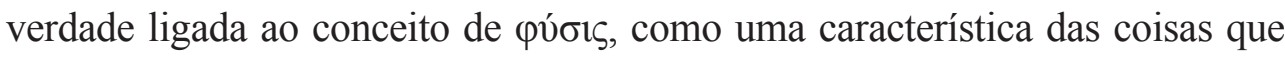

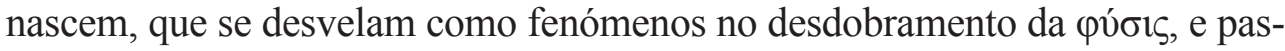
sou-se à verdade vinculada ao entendimento, à formulação de juízos, ou a Deus como a Verdade. Na modernidade, a verdade foi reduzida à certeza.

A pv́ఠıৎ lança-se num movimento de transcendência até constituir um ente, onde irrompe como liberdade, decisão e compromisso para com o ser, entendido como todo o possível. "O poder, o salto da origem [Ur-sprung] é a eclosão do próprio tempo, a sua ek-stase original, que produz o ente para o exterior, dispersando o seu ser pelos três modos de presentificação: o futuro, o passado e o presente" (BLANC, 1998 (a), p. 334).

O ser é um movimento de essenciação da verdade. A manifestação do ser é um processo temporal. O ser é pensado como um processo, um acto temporal de haver [geben], cuja dinâmica consiste num trazer-ao-aberto [ins Offene-Bringen] e desocultar [entbergen] (BLANC, 1998 (b), p. 197).

O tempo é o horizonte para a compreensão do ser. O tempo só se temporaliza como tempo enquanto existência histórica do homem (HEIDEGGER, 1997, p. 95). O ser desdobra-se na nossa existência.

Em Heidegger, o ser deixa de ser visto como um fundamento sólido e estável da verdade. O ser é visto como abismo e a verdade como velamento desvelante que permeia todos os entes. $\mathrm{O}$ que os gregos não pensaram foi a dimensão do retiro.

O que caracteriza o ser não é a permanência ou a presença constante, mas uma emergência abrupta ou súbita que demora e perdura. A verdade é experimentada como acontecimento. O não-estar-encoberto do ente, o desvelamento do ente, é um acontecimento. É o lugar da temporalização do tempo, o evento da irrupção do tempo. O ser deve ser entendido no seu caráter de acontecimento. O ser essencia-se como acontecimento apropriador (HEIDEGGER, 2014 (a), p. 256).

A verdade do ser não é nada menos que a essência da verdade, concebida e fundada enquanto velamento clareante, o acontecimento do ser-aí, do ponto de virada na viragem enquanto meio que se abre (HEIDEGGER, 2014 (a), p. 185). Ou seja, o evento da essenciação do ser, assim como faz advir a essência dos entes, inclui nessa sua eclosão o ser-aí, constituindo-o, pela temporalidade ekstática, clareira do seu manifestar-se, aberta ao desvelamento e à fundação da sua verdade (BLANC, 2012, p. 163). 


\subsection{A Clareira do Ser}

Heidegger recusou-se a pensar o ser como uma espécie de ente superior, fundamento eterno, causa de todas as coisas. Para algo 'ser' tem de se revelar, apresentar. E para que essa presença ou auto-manifestação ocorra é necessária uma clareira, um vazio. O Dasein é essa abertura necessária para que tenha lugar a presença dos entes. Dasein é a abertura na qual a presença se dá.

O Dasein distingue-se eminentemente de qualquer outro ente uma vez que ele possui a característica fundamental de estar sempre em relação com o seu ser e com o ser. O Dasein compreende-se sempre de qualquer maneira e mais ou menos explicitamente no seu ser. O ente humano é ontológico, aberto, reflexivamente transparente ao seu próprio ser e ao ser dos entes em geral. É importante notar que ser ontológico ainda não quer aqui dizer desenvolver uma ontologia, uma teoria do ser enquanto ser, pelo que o Dasein deve ser considerado pré-ontológico, não significando isso ser apenas do ponto de vista ôntico, mas ser um ente que compreende o ser.

Ao contrário do que acontece com os entes, o ser-aí não subsiste simplesmente, mas existe, pelo que Heidegger salienta que a essência do Dasein reside na sua existência. Existir é escolher esta ou aquela possibilidade de ser. De notar que, para Heidegger, a existência não tem o significado medieval de existentia, que significa literalmente ser subsistente, Vorhandenheit, aquilo que está diante da mão, presença, que caracteriza os entes que estão fechados sobre si próprios; a existentia é algo de estático. A existência de que nos fala Heidegger é ek-stática; caracteriza esse ente denominado Dasein, capaz de ser aquilo que projeta ser, de sair de si próprio, de ek-sistir. A essência do homem reside na ek-sistência (HEIDEGGER, 1973, p. 91). Ek-sistência significa estar exposto na verdade do ser. Dasein, ser-aí, ser o aí do ser, é radical abertura, poder ser.

O Dasein é um ser existindo, é um ser sendo, e enquanto ser existindo é necessariamente um acontecendo na temporalidade. O homem existe existindo; trata-se de uma espacialidade inserida na temporalidade. No Dasein manifestam-se, em cada momento da sua existência, as três dimensões do tempo - passado, presente e futuro. Mas é importante salientar que, quando Heidegger fala em futuro, não se refere ao momento que ainda não se realizou, porque isso seria colocar-se num plano ôntico de um escoar de instantes. Futuro, passado e presente são igualmente originais, constatando-se, contudo, o primado do futuro. O futuro é o lugar que traz o sentido da vida. Vem até nós na forma de uma possibilidade de vida.

A compreensão do ser, que é própria do Dasein, inclui, de maneira igualmente originária, a compreensão do mundo e a compreensão do ser dos entes que se tornam acessíveis dentro do mundo. Os entes intramundanos têm um sentido na 
medida em que são compreendidos e interpretados pelo Dasein. Por isso, Heidegger diz que o Dasein é um ente transparente; para ele e através dele as coisas aparecem e apresentam-se. O Dasein é o lugar onde o ser se desvela, onde o ser se dá.

A primeira característica da existência humana é ser-no-mundo' [In-der-Welt-sein], que não tem um significado espacial de um ente que se encontra num lugar denominado mundo, mas sim que o homem não pode conceber-se a não ser em relação essencial e constitutiva com o mundo. Ser-no-mundo é uma estrutura unitária que constitui um modo de ser do homem; não tem um significado ôntico, mas ontológico-existenciário. Este modo peculiar de se comportar é designado por cuidar de. Cuidar de é o modo como o Dasein está no mundo. Trata-se de um conceito estrutural ontológico. Por ser inerente ao Dasein o ser-no-mundo, o seu ser para com o mundo é essencialmente cuidado. Por cuidado deve entender-se deixar algo livre na sua própria essência. Sentir as coisas e deixá-las livres na sua própria essência. Fica, assim, bem claro por que motivo Heidegger considera que a essência da verdade é a liberdade, o deixar-ser dos entes, a entrega à desocultação do ente enquanto tal, confiar-se ao aberto e à sua abertura, numa exposição ao desvelamento do ente, que o pensamento ocidental primevo entendeu como

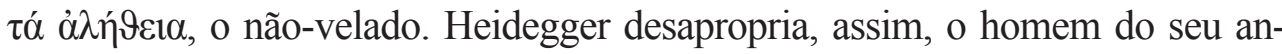
tropocentrismo. Restitui o homem à sua simplicidade última, à sua nudez, à sua dimensão de pastor. Cuidar do mundo é guardar os entes junto da sua verdade.

O Dasein não é algo inicialmente contido em si próprio que emerge para apreender outras coisas pré-constituídas do mundo, e o mundo não é um mero agregado de coisas, contáveis ou incontáveis, conhecidas ou desconhecidas, que se encontrem ante nós e que possam ser intuídas. Mundo significa a abertura do ser, a clareira do ser (HEIDEGGER, 1973, p. 99).

A verdade é a mundaneidade. A mundaneidade é sempre uma conjuntura de sentido, que é trazido pela interpretação. O mundo é o horizonte de sentido de cada humanidade, que implica uma certa interpretação da verdade. A verdade é equivalente ao sentido, o que determina as significações ônticas. É pela discursividade que chegamos ao sentido.

Na experiência grega inicial, nomeadamente nos textos de Heráclito, a palavra é aquilo que mostra [das Zeigende], ou seja, não é significado, signo, aquilo que designa [das Bezeichnende], mas origem das próprias coisas no seu ser, na linguagem vinda à presença, ou seja, em conexão íntima com o próprio ser. Para Heidegger, a linguagem torna possível a instauração do ser. $\mathrm{O}$ que faz de nós guardadores da verdade é a palavra. Essa é a excecionalidade do humano: "O Ser homem, segundo a sua essência histórica, que abre e manifesta a História, é Logos, (re)união e percepção do ser do ente (...)" (HEIDEGGER, 1997, p. 188). 
A verdade como fundamento abissal em Heidegger
Dnda. Ana Cristina

Reis Cunha [ULisboa]

A linguagem é portadora de sentido, constituído por uma interpretação do mundo. O verbo é a estrutura da compreensão e do sentir. Segundo Heidegger, o homem entra na essência das coisas através da linguagem, do dizer primordial, essencial, poético. Não se entenda, aqui, por poético, versos em rima, ou uma linguagem feérica. Poético significa o modo como a linguagem, com o seu vigor, ajuda a trazer à superfície o que se encontra encoberto nas coisas: o ser. Numa atitude poética, o homem demora-se junto das coisas, cuidando delas no respeito pela sua essência. O ser desvela-se ao homem como logos, como palavra, como sentido.

O Dasein é um espaço aberto, como uma clareira no seio da floresta. O Dasein não tem predicados, e caracteriza-se pela transcendência, pela possibilidade. A abertura constitutiva da existência humana é condição de toda a verdade, abrindo a possibilidade de que as coisas e ela própria apareçam sendo o que são.

\title{
3. A verdade como doação e retração
}

Ser ente implica vir à luz, apresentar-se, surgir. Não-Ser, ao invés, significa afastar-se do aparecimento, da presença. Na essência do aparecimento situa-se o surgir e o afastar-se. A interação da presença e da ausência, do desvelamento e da ocultação, da acessibilidade e da retirada, é central para o entendimento da verdade, da desocultação:

\begin{abstract}
A essência da verdade, i. e. o não-estar-encoberto, está transida por uma escusa [Verweigerung]. Este escusar-se, no entanto, não é uma falta ou um defeito, como se a verdade fosse um puro não-estar-encoberto que se tivesse livrado de todo o encoberto. Se o pudesse fazer, já não seria aquilo que em si mesma é. Este escusar-se, ao modo do duplo encobrir-se, é inerente à essência da verdade como não-estar-encoberto. A verdade é, na sua essência, não verdade. (HEIDEGGER, 2014 (b), pp. 54-55)
\end{abstract}

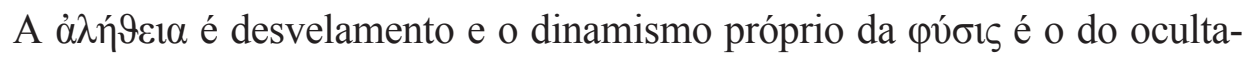
mento e desocultamento. $\mathrm{O}$ desocultamento provém de um ocultamento originário do ser. Para Heidegger, $\alpha \lambda \eta ́\} \varepsilon 1 \alpha$ não é puro desvelamento, mas o acontecer do jogo ocultamento/desocultamento: 
Com a verdade do ser, pretende o filósofo pensar o carácter negativo da $\dot{\alpha}-\lambda \hat{\eta} \vartheta \varepsilon ı \alpha$, em virtude do qual o desvelamento é sempre um não-velamento [Unverborgenheit], isto é, uma luta contra o velamento [Verborgenheit], o mistério [Geheimnis], em que o ser se envolve a si mesmo, e que assim constitui a natureza mais profunda da manifestação. (BLANC, 1998, p. 120).

Todo o desvelamento pressupõe um velamento, pelo que todo o conhecimento tem como contrapartida o mistério. "A verdade acontece como o encobrimento clareador." (HEIDEGGER, 2014 (a), p. 33). Ocultar-se não é encerrar-se, mas um albergar que guarda as possibilidades essenciais do abrir-se. "A verdade é não-verdade na medida em que faz parte dela o âmbito da proveniência do ainda-não (do não-) desencoberto, no sentido do encobrimento." (HEIDEGGER, 2014 (b), p. 62).

É retirando-se que o ser dá lugar ao sendo, ao ente. O ser é o que faz aparecer mas não aparece. É a eclosão, enigma absoluto:

O eterno não é o que per-dura, mas aquilo que se pode subtrair no instante, a fim de retornar uma vez mais. O que pode retornar não como o igual, mas como o novamente transformador, uno-único, o ser, de tal modo que ele não é reconhecido nessa manifestabilidade de saída como o mesmo! (HEIDEGGER, 2014 (a), p. 361).

O processo da existência não passa pela mediação de essências. A essência como essenciação não é representável, não reside acima do ente e cindida dele.

O ser desdobra-se em cada ente na sua singularidade própria. O ser é experimentado e pensado como o que acontece coetaneamente com o ente, como o seu fundamento, não como causa. $\mathrm{O}$ estremecimento do ser não causa nem cria nada. $\mathrm{O}$ ser não é um hiper-ente que cause o ente. $\mathrm{O}$ acontecimento é apenas uma doação do ser.

O ser essencia-se como a verdade do ente. O ser não é algo de fixo e indeterminado, mas um movimento de exteriorização, de desdobramento de si, que, sem nunca sair de si, irradia e difunde-se, lançando os entes para o aberto da existência.

O ser é um dar de si. O puro dar, que faz com que o ente apareça, ele próprio não ocorre nem aparece, antes reenvia para isso que dá [Es gibt], que o filósofo 
designa por Ereignis, evento de apropriação (BLANC, 2012, p. 135). Não se trata de um evento ôntico, mas ontológico.

Heidegger salienta que o ser não é algo anterior, subsistindo por si e em si, mas o Ereignis, evento ou acontecimento apropriador, é a coetaneidade para o ser e o ente (HEIDEGGER, 2014 (a), p. 17). Não há prioridade mas simultaneidade. A verdade do ser não é um a priori à essenciação do ser.

A essência do ser, longe de se exibir na realidade efetiva [Wirklichkeit], antes se retrai e retira. A $\alpha \lambda \eta \dot{\vartheta} \vartheta \varepsilon 1 \alpha$, o mistério de haver ser [es gibt Sein], não constitui um enigma suscetível de ser explicado racionalmente, mas um dom que o pensar só pode acolher e fazer frutificar através da palavra poética (BLANC, 2001, p. 189).

O Ereignis não é um fundamento que possa ser compreendido e objetivado, antes indica o modo e o âmbito do dar-se do ser, o puro acontecimento que deixa vir os entes à presença, subtraindo-se, contudo, a esta. Ereignis é, assim, doação e retração. É retraindo-se que o ser concede aos entes vir à presença.

O Ereignis situa-se no plano da ação, o puro eclodir, dar-se do ser como vinda à presença do ente, num essenciar-se que, ao mesmo tempo que envia e destina, se retêm. Furta-se a toda a apreensão uma vez que, na sua ação centrífuga, pondo tudo em caminho, ele se desapropria a si mesmo em prol daqueles que envia (BLANC, 2012, p. 163).

O que está na base do fenómeno é a dimensão do dom, da gratuidade. O movimento de essenciação do ser é uma doação. Estando na base de toda a manifestação, todavia subtrai-se. O dom é essa retração inerente ao haver algo. É a retração da doação como tal.

Heidegger convida-nos a fazermos, de novo, a experiência da sacralidade da manifestação do ser, do seu caráter de dom, de maravilha. Refere o filósofo na Carta sobre o Humanismo: "Talvez o elemento mais marcante desta idade do mundo consista no rígido fechamento para a dimensão da graça. Talvez seja esta a única desgraça." (HEIDEGGER, 1973, p. 102). Constata-se, na modernidade, a recusa do dom, pois o homem é a única fonte de verdade.

O Ereignis é o evento que dá sentido, mas, ele próprio, não tem sentido, é o excesso último, entendendo-se por excesso aquilo que está para além da nossa compreensão. Isto significa que o Ereignis não pode ser percebido, revelado ou interpretado da mesma maneira que os entes. Ele permanece intrinsecamente opaco ou, pelo menos, resistente à compreensão ordinária: “A medida excessiva não é nenhuma mera demasia quantitativa, mas o subtrair-se a toda avaliação e mensuração." (HEIDEGGER, 2014 (a), p. 245). 
A verdade como fundamento abissal em Heidegger
Dnda. Ana Cristina

Reis Cunha [ULisboa]

\section{O excesso ontológico ou o mistério do ser}

\subsection{A secreta luminosidade do ser}

A $\alpha \lambda \eta \dot{\vartheta} \varepsilon 1 \alpha$ é a claridade que capta o olhar e se dá e habita no que está privado de claridade. É o desvelamento que abriga em si toda a emergência e toda a aparição e ocultação.

A $\dot{\alpha} \lambda \hat{Y} \ni \varepsilon ı \alpha$ é a essência do verdadeiro: a verdade. Esta reina sobre tudo o que desdobra o seu ser e é a própria essência de toda a essência: a essencialidade. "Como essência da emergência ( $\varphi v ́ \sigma ı)$ ), a $\alpha \lambda \eta ́ \vartheta \varepsilon ı 1 \alpha$ é o próprio começo." (HEIDEGGER, 2011, pp. 260-261).

$\mathrm{O}$ ser vem à luz como ser do ente. $\mathrm{O}$ aparecer tem o seu fundamento no puro brilhar, entendido como luzir emergente (HEIDEGGER, 2011, pp. 221-222).

Não é fácil, contudo, captar a luminosidade do ser. Salienta Heidegger que o próprio aparecer é um mostrar-se que encontra uma perceção e um acolhimento. Mas a perceção pode agarrar aquilo que se mostra como aquilo que é somente captado pela perceção e deixar escapar como algo de acessório, e finalmente esquecê-lo, o aparecer que se desdobra no mostrar-se, ou seja, o aparecer no sentido do puro brilhar e emergir.

A verdade é concebida como encobrimento clareador (HEIDEGGER, 2014 (a), p. 300). Não é, assim, numa relação dicotómica sujeito-objeto que o homem, ipseidade confrontando-se com o que perceciona em seu redor, poderá ser iluminado pela luz da verdade, mas apenas numa atitude de despojamento e total abertura, como o aí do ser, clareira do ser:

Na noite clara da angústia, despojada de toda a identificação, expectativa ou memória, a consciência já não se determina como consciência de, intencional, antes se perfila como consciência de nada, pura vacuidade. Assim, prostrada, abandona-se e desvanece-se como autoconsciência até que, ao raiar do dia, um toque penetrante de luz a pervaga e desperte.

Numa passividade radical que supõe a inversão de toda a intencionalidade faz, então, a experiência pura, extática, de um poder originante, em que se encontra fundada e que é a base de toda a experiência. Não se trata de um saber intelectivo de visão, mas de descoberta, da prova existencial e afectiva de 
A verdade como fundamento abissal em Heidegger
Dnda. Ana Cristina

Reis Cunha [ULisboa]

uma presença irrecusável, mas obscura e transcendente, que opera na consciência um consentimento e uma entrega gratuita total. (BLANC, 2010, p. 289).

Em Heidegger, o dom absoluto preside à existência. A doação do ser é amor, pelo que não é pela razão mas pela disposição afetiva que acedemos ao ser. O ser está fora do espaço categorial do entendimento e é da ordem da essenciação. O ser dá-se em nós. A forma de aceder ao ser faz-se pela via da imanência, uma vez que ele está na relação com a nossa própria existência. É uma imanência que nos excede, que é abissal.

A filosofia de Heidegger é uma filosofia da total imanência e da total transcendência.

\subsection{O fundamento abissal}

O princípio do fundamento afirma: nada é sem fundamento, nihil est sine ratione. O princípio do fundamento pode ser interpretado de duas maneiras distintas. Pode interpretar-se como 'cada ente tem um fundamento', em que o princípio do fundamento é um enunciado sobre o ente. O ser chega à aparência enquanto ente que é razão, causa do existente. Mas o mesmo princípio pode ser interpretado como significando 'ao ser pertence fundamento'. Há aqui uma mudança de tonalidade, como salienta Heidegger em O Princípio do Fundamento.

Ser é, na essência, fundamento. Mas o ser fundador não pode ter, ele próprio, um fundamento, na medida em que ele é o fundamento. Enquanto fundamento, ele é sem fundo, abissal. O ser não tem porquê. É porque é. "Na medida em que o ser enquanto tal é fundamentado em si próprio, permanece ele mesmo sem fundamento.”(HEIDEGGER, 1999, p. 81).

O fundamento não é uma realidade objetiva substancial com a qual o pensamento se confronta na indagação do princípio último das coisas, algo já dado a partir do qual resultou aquilo que é. Por isso, em Beiträge zur Philosophie (Vom Ereignis), Heidegger opta pelo termo fundação, ato de fundar que está sempre a criar aquilo que é. A fundação remete para um Ereignis, um acontecimento inaugural e constituinte. "O a-bismo é a essenciação originária do fundamento. O fundamento é a essência da verdade. (...) O a-bismo é o permanecer de fora do fundamento.” (HEIDEGGER, 2014 (a), p. 369).

Dos princípios não há demonstração: o fundamento não pode estar no fundamentado. O começo não deixa que apareça o seu carácter de começo, que se man- 
A verdade como fundamento abissal em Heidegger
Dnda. Ana Cristina

Reis Cunha [ULisboa]

tém reservado na sua própria intimidade. $\mathrm{O}$ começo mostra-se em primeiro lugar no que provém dele, mas mesmo aí ele nunca se mostra a não ser como aquilo que começou. Mesmo se o que dele provém aparece como tal, o que começa e toda a essência do começo podem ainda permanecer velados. O começo desvela-se, assim, no que dele emana e já dele, de certa forma, procedeu. $\mathrm{O}$ começo deixa, inicialmente, atrás de si, a proximidade da sua essência inicial e assim a vela. É por isso que a experiência do que é inicial nunca garante ela mesma a possibilidade de pensar o próprio começo na sua essência. (HEIDEGGER, 2011, p. 220).

O velamento do inicial deve ser preservado. "É preciso evitar todo e qualquer deslocamento por meio de tentativas de explicação, uma vez que, necessariamente, tudo o que explica jamais alcança o início, mas apenas o rebaixa a si." (HEIDEGGER, 2014 (a), p. 184).

O ser, o «é» de um ente, não está enraizado no ente, como se pudessemos extrair o ser do ente. $\mathrm{O}$ ser não mergulha as suas raízes em nenhum solo, é o sem-fundo. $\mathrm{O}$ sem-fundo, originariamente desprovido de solo e das falhas que todo o solo comporta, é o que abriga de uma maneira inicial. $\mathrm{O}$ aberto, enquanto tal, abriga a morada essencial do homem, na medida em que ele e apenas ele é o ente para o qual o ser vem à luz. (Heidegger, 2011, p. 242)

Ao ser, enquanto fundamento abissal, pertence o nada. A abissalidade é o caráter retrativo da $\dot{\alpha} \lambda \hat{\eta} \vartheta \varepsilon ı \alpha$.

A essenciação do ser nos entes dá-se no tempo-espaço: "O a-bismo como primeira essenciação do fundamento funda (deixa o fundamento se essenciar como fundamento) sob o modo da temporalização e da espacialização." (HEIDEGGER, 2014 (a), p. 372).

Heidegger discorda do pensamento ocidental em que tempo e espaço são considerados independentes um do outro. O espaço cartesiano é extensão geométrica, mas para o autor em análise, o espaço é um espaço poético, uma clareira de verdade. $\mathrm{O}$ a priori do sentido é de natureza linguística, interpretativa, um espaço existencial, semântico. A linguagem chama-nos à abertura da verdade. $\mathrm{O}$ espaço físico é aberto pelo sentido, constituído pela imaginação, pela temporalização do tempo.

Com Kant, o espaço passou a ser forma da intuição sensível, mas o filósofo não se interrogou sobre a essência do espaço. O espaço espaceia, abre clareiras. O espaço está associado ao sentido e não ao corpo. O espaço matemático destruiu a estrutura do horizonte de sentido.

O tempo-espaço pertence à verdade no sentido da re-essenciação do ser como acontecimento apropriador. O tempo-espaço é a abertura de um fosso abissal apropriada em meio ao acontecimento nas vias da viragem do aconte- 
A verdade como fundamento abissal em Heidegger
Dnda. Ana Cristina

Reis Cunha [ULisboa]

cimento apropriador. O tempo e o espaço não pertencem ao sujeito, ou à consciência, mas ao abismo do acontecimento. "Tempo e espaço (originariamente) não «são», mas se essenciam." (HEIDEGGER, 2014 (a), p. 375). Tempo-espaço é o elemento abissalador do fundamento: a essenciação da verdade. É o desdobramento essencial da essenciação da verdade.

O tempo-espaço remete à verdade como abertura originária do ser. No evento, no Ereignis, que o próprio ser constitui enquanto movimento de essenciação, desdobra-se o espaço de jogo temporal. O espaço é um movimento de espacialização que resulta de um dinamismo de temporalidade, da temporalização do tempo.

O evento do ser é a sua essenciação, eclosão, em formas distintas de temporalização do tempo e de espacialização, e a verdade é, assim, fonte abissal, que contém possibilidades inesgotáveis de começo.

\section{Conclusão}

É colossal o empreendimento de Heidegger, pensar o ser no seu ser, reeditando o radicalismo de uma atitude questionadora e pensante esquecida. A marca deste autor está na exigência de um pensar autêntico, um pensar que dá a palavra à própria coisa e deixa que ela se mostre na sua originalidade.

Heidegger alerta para a necessidade de se pensar o ser enquanto ser, não como um ente supremo, causa de todos os entes, mas o ser como tal. Não é, assim, através da dicotomia sujeito-objeto que se deve colocar a pergunta acerca do ser, uma vez que o ser é indefinível e inapreensível. Só recusando a abordagem presencialista se pode pensar o ser. Para tal intento escolheu Heidegger a hermenêutica, na linha de Dilthey.

A essência da verdade como $\alpha \dot{\lambda} \eta \dot{\vartheta} \varepsilon 1 \alpha$ permaneceu impensada, tanto pelos gregos como na filosofia posterior. O ser permaneceu impensado pela metafísica, pelo que a história da metafísica pode ser concebida como a história do esquecimento do ser.

A filosofia de Heidegger é um pensar preparatório do pensar futuro. Prepara a possibilidade de uma nova história, uma história em que o ser aparece na sua relação direta com o homem e em que este se abre àquilo a que é chamado a ser: o guardador do ser.

O que está em jogo é uma transição, a proposta de uma nova ontologia, uma mudança de civilização. Pensar o ser como Ereignis remonta à origem da mani- 
A verdade como fundamento abissal em Heidegger
Dnda. Ana Cristina

Reis Cunha [ULisboa]

festação. Prepara um outro início da história. Para isso, Heidegger convida-nos a uma ascese, à aprendizagem que o ser não se compagina com o ter, com a queda na posse, na segurança.

O esquecimento da dimensão de possibilidade, da dimensão de sentido, está na origem da queda do homem, que se deixa objetivar. O homem moderno precisa de certezas, mas tem de largar mão das certezas para se abrir às possibilidades. O desconhecido do futuro convida-nos a uma criação. É um salto no escuro, para o abismo, o desconhecido.

Heidegger reabilita o conceito platónico de essência, mas interpreta-a num sentido temporal. Retira-lhe a dimensão estática, porque o ser é acontecimento. O ser é acontecimento porque é vida. Não há um plano de verdade inamovível acima do homem. Tudo se joga na existência, na vida. O ser dá-se inteiramente nos fenómenos. Heidegger pensa o ser como Ereignis, evento da manifestação, da vinda ao presente. É a génese contínua da temporalização do tempo.

$\mathrm{O}$ pensar da nova ontologia deve remontar à origem. $\mathrm{O}$ fenômeno originário dá-se na essenciação, na gênese de cada coisa. Em contraposição com Hegel, que defendia que o espírito vai progredindo no tempo e no fim está a verdade, em Heidegger é na fonte que se encontra a verdade. Trata-se de uma fonte abissal, que contém possibilidades inesgotáveis de começo.

Enquanto que na obra Sein und Zeit, publicada em 1927, Heidegger trata da questão do sentido do ser, centrando-se na analítica existencial do ente que se interroga sobre o sentido do ser, o Dasein, em Beiträge zur Philosophie (Vom Ereignis) tenta uma nova abordagem do ser que se funda na experiência fundamental do Ereignis do ser, do acontecimento do ser, da essenciação do ser como temporalidade e historicidade, que só ocorre no espaço cênico do Dasein.

Segundo Heidegger, a partir de Sócrates deu-se, no Ocidente, uma subordinação a uma epistëmë que subjuga o homem a um quadro fixo de valores e à vontade de domar a transcendência, de dominar a origem, através da técnica. $\mathrm{O}$ tempo passou a ser quantificado e pensado a partir do espaço. Em vez do tempo kairológico, passou-se a ver o tempo como cronológico, linear. Na compreensão métrica do tempo, na sua matematização, tudo é pensado a partir do presente e a história aniquila a historicidade. Tudo isto nos conduziu ao niilismo. O niilismo é a falta de sentido da existência.

O ser não é um ente. O ser não é uma quididade, não é redutível às formas categoriais da razão humana. O ser não é da ordem da presença, é da ordem da temporalização do tempo. Pensar é um exercício da temporalidade. Não é categorial, nem proposição apofântica predicativa da lógica, que petrifica as coisas. 
A verdade do ser é a essência da verdade. O ser é um movimento de essenciação da verdade. A verdade como fundamento abissal indicia, com a sua aura de inefabilidade, de inescrutabilidade, o excesso ontológico, o mistério do ser. Lévinas. Paris: J. Vrin, 1986.

Recebido em: 03.05.2018 | Aprovado em: 03.08.2018

BLANC, M. F. Crise do Sentido e Tarefa do Pensar. Lisboa: Centro de Filosofia da Universidade de Lisboa, 2010.

- Estudos sobre o Ser. Lisboa: Fundação

Calouste Gulbenkian, 1998 (a).

Estudos sobre o Ser II. Lisboa: Fundação

Calouste Gulbenkian, 2001.

O Fundamento em Heidegger. Lisboa:

Instituto Piaget, 1998 (b).

O Programa Filosófico de Heidegger. In:

Phainomenon, Revista de Fenomenologia, No 24,

Primavera 2012, 125-167.

HEIDEGGER, M. Contribuições à Filosofia (Do Acontecimento Apropriador). Rio de Janeiro: Editora Via Vérita, 2014 (a).

. A Origem da Obra de Arte. In: HEIDEGGER,

M. Caminhos de Floresta. Lisboa: Fundação Calouste Gulbenkian, 2014 (b), 3ª edição.
. Ser e Tempo (edição em alemão e português). Petrópolis: Editora Vozes, 2012.

- Parménide. Paris: Éditions Gallimard, 2011.

O Princípio do Fundamento. Lisboa: Instituto Piaget, 1999.

Introdução à Metafísica, Lisboa, Instituto Piaget, 1997.

. Carta sobre o Humanismo. Lisboa: Guimarães \& $C^{a}$ Editores, 1973.

ZARADER, M. Heidegger et Les Paroles de L'Origine, Prefácio de Emmanuel Lévinas. Paris: J. Vrin, 1986.

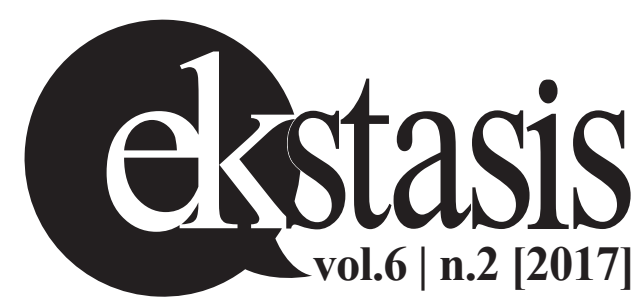

